\title{
ANALISIS PERILAKU WAJIB PAJAK UMKM TERHADAP PELAKSANAAN PEMUNGUTAN PAJAK DENGAN MENGGUNAKAN SELF ASSESSMENT SYSTEM DI KOTA TOMOHON
}

\author{
Trianita Putri ${ }^{1}$, David P. E. Saerang ${ }^{2}$, Novi S. Budiarso ${ }^{3}$ \\ 1,2,3 Jurusan Akuntansi, Fakultas Ekonomi dan Bisnis Universitas Sam Ratulangi, Jl. Kampus Bahu, Manado, \\ 95115, Indonesia \\ E-mail: trianitawputri@gmail.com
}

\begin{abstract}
The self assessment system is a tax collection system that gives trust to taxpayers to calculate, pay and self-report the amount of tax that should be owed based on applicable tax laws and regulations. This study aims to (1) know the implementation of the self assessment system in the city of Tomohon (2) to know the knowledge of tax (3) to know the implementation of tax obligations (4) to know the sensitivity and compliance with changes in taxation. This type of research is descriptive qualitative by taking primary data directly through interviews with 10 taxpayer informants in Tomohon city who have met the criteria. The results of the study indicate that the implementation of the self assessment system in Tomohon City has not gone well due to lack of tax knowledge and counseling which is rarely held by the government (tax authorities).
\end{abstract}

Keywords: Taxpayer behavior, Implementation of Tax Collection, Self Assessment System

\section{PENDAHULUAN}

Indonesia adalah negara yang sedang berkembang dan terus berupaya melakukan pembangunan di berbagai bidang sektor. Tercatat sekitar 2.080,5 trilliun rupiah APBN dihabiskan guna menunjang pembangunan nasional baik untuk pemerintah pusat maupun daerah dan pedesaan. Dalam data APBN 2017, ditetapkan jumlah pendapatan negara sebesar 1.750,3 trilliun rupiah. Terdiri dari beberapa penerimaan mulai dari penerimaan pajak sebesar 1,489,9 trilliun rupiah, penerimaan negara bukan pajak (PNBP) sebesar 250 trilliun rupiah hingga penerimaan hibah sebesar 1,4 trilliun rupiah. Berdasarkan data tersebut, tentunya kita bisa paham bahwa pajak memegang peran penting keberhasilan pembangunan negara. Ada beberapa masyarakat kurang paham dengan arti pajak sebenarnya dan merasa ada keterbebanan dalam melaksanakan pembayaran. Membayar pajak tepat waktu adalah wujud nyata kontribusi masyarakat ikut serta membangun negara. Berimbas pada pembangunan yang mengalami keterlambatan dari waktu yg telah ditentukan dan yang paling buruk adalah tertundanya proyek pembangunan tersebut. Jika tingkat keterlambatan membayar pajak terus menerus meningkat tidak menutup kemungkinan bahwa akhirnya proyek pembangunan berhenti total. Itu sebabnya kita masyarakat terlebih lagi yang seharusnya terdaftar sebagai wajib pajak harus sadar akan kepentingan pembangunan bersama.

Umumnya penerapan pemungutan pada pajak yang rutin dan tetap telah diterapkan pada masa kolonial Belanda. Akan tetapi di masa kerajaan dulu juga telah ada pungutan layaknya seperti pajak yaitu, pungutan yang semata-mata diberikan pada raja yang memerintah. Seiring berjalannya perubahan, bentuk upeti yang diserahkan oleh penduduk tidak hanya untuk keperluan sang raja saja, tetapi sudah lebih kepada kepentingan penduduk itu sendiri. Sistem self assessment adalah sebuah sistem pemungutan pajak yang memberikan kepercayaan kepada Wajib Pajak (WP) untuk menjalankan kewajibannya sendiri mulai dari menghitung, membayar sampai melaporkan jumlah pajak yang seharusnya terutang berdasarkan peraturan perundang - undangan perpajakan yang berlaku. Dengan begini 
masyarakat sebagai Wajib Pajak diberikan kesempatan untuk ikut berperan dalam pemungutan pajak. Dalam Sistem self assessment, peran pemerintah (fiskus) justru terbilang pasif, yaitu hanya sekedar memberikan penyuluhan dan pengawasan Wajib Pajak dalam pemenuhan kewajiban perpajakannya sendiri.

Sejak masa orde baru, Usaha Mikro, Kecil dan Menengah salah satu dari fondasi kuat pembangunan nasional. Dari tahun ke tahun kontribusi UMKM meningkat membuatnya menjadi penunjang pertumbuhan ekonomi di Indonesia. Selain kontribusinya yang nyata, UMKM juga ikut serta membantu menurunkan angka pengangguran dengan menyerap tenaga kerja. Kota Tomohon adalah kota subur yang sedang berkembang dan pertumbuhan ekonominya melaju pesat. Majunya suatu daerah tentunya cerminan dari pendapatan daerah yang mengalami peningkatan baik pendapatan dari pajak maupun pendapatan bukan berasal dari pajak. Tujuan penelitian ini adalah untuk mengetahui pelaksanaan self assessment di kota Tomohon lewat analisis perilaku wajib pajak, tingkat kepahaman atau pengetahuan masyarakat wajib pajak UMKM, pelaksanaan kewajiban perpajakan wajib pajak UMKM serta tingkat kepekaan wajib pajak UMKM terhadap setiap perubahan-perubahan yang dilakukan oleh pemerintah (fiskus).

\section{TINJAUAN PUSTAKA}

Pengertian dari Akuntansi. Menurut Warren dkk (2005:10), menjelaskan bahwa secara umum, akuntansi dapat didefinisikan sebagai sistem informasi yang menghasilkan laporan kepada pihak-pihak yang berkepentingan mengenai aktivitas ekonomi dan kondisi perusahaan. Sedangkan Soemarsono (2004), mengatakan Akuntansi merupakan proses mengidentifikasikan, mengukur dan melaporkan informasi ekonomi untuk memungkinkan adanya penilaian dan keputusan yang jelas dan tegas bagi mereka yang menggunakan informasi tersebut. American Accounting Association, akuntansi merupakan proses identifikasi, pengukuran dan pelaporan informasi ekonomi untuk memungkinkan adanya penilaian dan keputusan yang jelas serta tegas bagi pengguna informasi tersebut. Financial Accounting Standars Board (FASB), menyatakan bahwa akuntansi ialah sebuah kegiatan jasa yang fungsinya menyediakan informasi kuantitatif yang kemudian dipakai untuk pengambilan keputusan ekonomi. Berdasarkan pendapat para ahli yang telah diuraikan di atas, maka peneliti mengambil kesimpulan bahwa Akuntansi adalah proses pencatatan mulai dari mengidentifikasi transaksi melalui bukti transaksi dengan membuat jurnal kemudian mengklasifikasikannya ke dalam buku besar, neraca saldo dan penyesuaiannya hingga menghasilkan ikhtisar laporan keuangan utuh yang nantinya digunakan untuk para pengambil keputusan atau pihak yang memerlukan informasi tersebut.

Akuntansi Pajak. Akuntansi pajak merupakan perhitungan tentang besarnya pajak terutang berdasarkan laporan keuangan yang disusun oleh perusahaan (Agoes dan Estralisa 2013:10). Jadi Akuntansi pajak menghasilkan laporan yang menerangka tentang pajak-pajak apakah yang dihitung, dipotong, dibayar serta dilaporkan suatu organisasi.

Pengertian Pajak. Soemitro di dalam buku Perpajakan Mardiasmo (2016: 3), menjelaskan bahwa pajak adalah iuran rakyat kepada kas negara berdasarkan undang-undang (yang dapat dipaksakan) dengan tiada mendapat jasa timbal balik (kontraprestasi) yang langsung dapat ditunjukan dan yang digunakan untuk membayar pengeluaran umum.

\section{Sistem Self Assessment}

Pengertian Sistem Self Assessment. Menurut Waluyo (2013:17), bahwa sistem ini ialah pemungutan pajak yang di memberi wewenang kepercayaan, tanggungjawab kepada wajib pajak untuk menghitung, memperhitungkan, membayar dan melaporkan sendiri besarnya pajak yang harus dibayar. 
Ciri dan Corak Sistem Self Assessment. Menurut Zain (2008:113), ciri dan corak tersendiri dari sistem pemungutan pajak dengan sistem self assessment adalah sebagai berikut:

a. Pemungutan pajak merupakan perwujudan dari pengabdian kewajiban dan peran serta Wajib Pajak untuk secara langsung dan bersama-sama melaksanakan kewajiban perpajakan yang diperlukan semata-mata untuk pembiayaan negara dan pembangunan nasional.

b. Tanggung jawab atas kewajiban pelaksanaan pajak, sebagi cerminan pada anggota masyarakat Wajib Pajak sendiri. Pemerintah, dalam hal ini aparat perpajakan sesuai dengan fungsinya berkewajiban melakukan pembinaan, penelitian, dan pengawasan terhadap pelaksanaan kewajiban perpajakan Wajib Pajak berdasarkan ketentuan yang digariskan dalam peraturan perundang-undangan perpajakan.

c. Anggota masyarakat Wajib Pajak diberi kepercayaan untuk dapat melaksanakan kegotongroyongan nasional melalui sistem menghitung, memperthitungkan, dan membayar sendiri pajak yang terutang (self assessment), sehingga melalui sistem ini pelaksanaan administrasi perpajakan diharapkan dapat dilaksanakan dengan lebih rapi, terkendali, sederhana dan mudah untuk dipahami oleh anggota masyarakat Wajib Pajak.

Pelaksanaan Sistem Self Assessment. Siti Kurnia (2018:103), mengemukakan bahwa sistem self assessment menyebabkan wajib pajak mendapat beban berat karena semua aktivitas pemenuhan kewajiban perpajakan dilakukan oleh Wajib Pajak sendiri. Berikut adalah kewajiban-kewajiban dari wajib pajak dalam melaksanakan self assessment system, yaitu: (1) mengukuhkan diri sebagai pajib pajak di kantor pelayanan pajak; (2) menghitung pajak terutangnya sendiri oleh wajib pajak; dan (3) membayar hingga melaporkan pajaknya oleh wajib pajak itu sendiri.

Wajib Pajak. Wajib Pajak ialah orang pribadi atau badan meliputi pembayar pajak, pemotong pajak dan pemungut pajak yang mempunyai hak dan kewajiban sesuai dengan ketentuan perundang-undangan perpajakan ditentukan untuk melakukan kewajiban perpajakan termasuk pemungut pajak dan pemotong pajak tertentu (pasal 1 butir 2 UU KUP).

Perilaku Wajib Pajak. Menurut Louis Thurstone et al, perilaku merupakan sebuah bentuk dari evaluasi atau reaksi perasaan. Berarti sikap seseorang terhadap suatu objek adalah perasaan memihak atau mendukung (favorable) maupun perasaan tidak memihak atau tidak mendukung (unfavorable) pada objek yang disebutkan. Teori Perilaku Terencana (Theory of Planned Behavior) adalah teori penyempurnaan dari Theory of Reasoned Action yang dikemukakan oleh Ajzen (2005) dan menjelaskan bahwa perilaku dipengaruhi oleh faktorfaktor seperti:

1. Konsekuensi dari perilaku. Menurut Ajzen (2005), menerangkan bahwa perilaku-perilaku yang terjadi ditetapkan oleh kepercayaan mengenai apa akibat dari sebuah perilaku atau singkatnya disebut kepercayaan-kepercayaan perilaku (behavioral beliefs).

2. Norma subjektif. Norma subjektif adalah pendapat tiap orang terhadap keinginan yang bearasal orang-orang sekitar yang mempengaruhi pada kehidupannya (significant others) tentang dilaksanakan atau tidak dilaksanakannya perbuatan tertentu seperti, keluarga, teman dan orang-orang lainnya yang memotivasinya melakukan perilaku tersebut.

3. Persepsi kontrol peilaku (perceived behavioral control). Persepsi atau pendapat kontrol perilaku merupakan pendapat perorangan tentang gampang atau susahnya melaksanakan sebuah perilaku tertentu. Tentang seberapa kuat hal tersebut mempengaruhinya dalam melakukan tindakan perilaku tersebut.

Usaha Mikro, Kecil dan Menengah. Menurut Undang - Undang No. 20 Tahun 2008

Pasal 1, Usaha Mikro, Kecil dan Menengah merupakan :

1. Usaha Mikro ialah usaha produktif milik orang perorangan dan/atau badan usaha perorangan yang memenuhi kriteria Usaha Mikro sebagaimana diatur dalam Undang Undang ini. 
2. Usaha Kecil ialah usaha ekonomi produktif yang berdiri sendiri, yang dilakukan oleh orang perorangan atau badan usaha yang bukan merupakan anak perusahaan atau bukan cabang perusahaan yang dimiliki, dikuasai, atau menjadi bagian baik langsung maupun tidak langsung dari Usaha Menengah atau Usaha Besar yang memenuhi kriteria Usaha Kecil sebagaimana dimaksud dalam Undang-Undang ini.

3. Usaha Menengah ialah usaha ekonomi produktif yang berdiri sendiri, yang dilakukan oleh orang perorangan atau badan usaha yang bukan merupakan anak perusahaan atau cabang perusahaan yang dimiliki, dikuasai, atau menjadi bagian baik langsung maupun tidak langsung dengan Usaha Kecil atau Usaha Besar dengan jumlah kekayaan bersih atau hasil penjualan tahunan sebagaimana diatur dalam Undang- Undang ini.

\section{METODE PENELITIAN}

Jenis dan sumber data. Penelitian ini menggunakan metode kualitatif dengan pendekatan deskriptif dengan data yang digunakan adalah data kualitatif. Sumber data dalam penelitian ini adalah data primer. Data primer yang digunakan adalah wawancara langsung dengan Wajib Pajak di Kota Tomohon. Penelitian ini berfokus pada wajib pajak UMKM dengan kriteria, memiliki penghasilan dari kegiatan usahanya dan memenuhi persyaratan dikenakan pajak atas penghasilan tersebut, mempunyai NPWP dan bertempat tinggal di kota Tomohon. Metode pengumpulan data melalui wawancara dan dokumentasi.

Metode Analisis. Metode analisis data yang digunakan adalah analisis deskriptif, yaitu peneliti mendeskripsikan semua temuan atau fakta - fakta yang ada dilapangan atas fenomena atau kejadian yang ada dimasyarakat kemudian diolah dan ditarik kesimpulan atas data -data yang telah didapat melalui hasil wawancara. Proses analisis mulai dari mengumpulkan data wawancara dari narasumber, kemudian dari hasil wawancara data tersebut diolah dalam bentuk tulisan agar mempermudah proses analisis dan terakhir menarik kesimpulan dari data yang telah diolah tersebut sehingga menghasilkan solusi.

\section{HASIL PENELITIAN DAN PEMBAHASAN}

\subsection{Hasil Penelitian}

Pelaksanaan Self Assessment System di Kota Tomohon. Pada penelitian ini, terdapat enam belas wajib pajak UMKM terdiri dari tiga pemilik usaha rumah makan, tujuh penjual bunga potong/hias dan enam penjual kerajinan bambu yang bersedia diwawancarai, tetapi hanya sepuluh wajib pajak UMKM yang memenuhi kriteria sebagai informan dan sisanya belum mendaftarkan diri untuk kepemilikan NPWP. Dengan sepuluh informan wajib pajak UMKM ini dapat memberikan jawaban beragam atas pelaksanaan self assessment system yang telah berjalan. Informan paling banyak dalam penelitian ini berasal dari $60 \%$ usaha jual bunga potong/hias, $20 \%$ usaha jual kerajinan bambu dan $20 \%$ usaha rumah makan. Melalui serangkaian wawancara terdapat hasil dua informan wajib pajak UMKM yang melaksanakan sistem self assessment dan delapan informan wajib pajak UMKM lainnya belum melaksanakannya dengan baik.

Pemahaman Pajak pada Wajib Pajak UMKM Kota Tomohon. Dalam penelitian ini, informan dinilai tentang pengertian pajak, peran pajak untuk negara, sistem perpajakan dan tarif pajak yang berlaku saat ini. Dua informan hanya menjelaskan lebih kepada jenisjenis pajak bukan pengertian pajak serta tidak tahu tentang sistem pajak dan tarif pajak yang berlaku, lima informan diantaranya mampu menjelaskan pengertian pajak, perannya untuk negara hingga tarif pajak tetapi kurang tahu tentang sistem perpajakan dan hanya tiga informan dengan kelompok usaha yang berbeda mampu memberikan penjelasan pemahaman tentang pajak secara lengkap.

Pelaksanaan Kewajiban Wajib Pajak UMKM Kota Tomohon. Informan dinilai tentang pelaksanaan kewajiban perpajakannya sebagai wajib pajak UMKM melalui mulai 
dari fungsi menghitung, fungsi membayar hingga fungsi melapor. Terdapat tiga informan yang menjalankan kewajiban dengan baik mulai dari menghitung, membayar dan melapor dan dua diantaranya menggunakan jasa konsultan pajak atau ahli perpajakan. Tujuh informan lainnya hanya menjalankan salah satu fungsi dan paling banyak tidak menjalankan fungsi membayar dan melapor tepat waktu.

Kepekaan Wajib Pajak UMKM Kota Tomohon Terhadap Perubahan pada Perpajakan. Kepekaan yang dinilai adalah perubahan tarif, kebijakan dan penerapannya. Dari sepuluh informan yang memenuhi kriteria hanya terdapat tiga informan yang benar peka terhadap adanya perubahan pada perpajakan. Tujuh informan lainnya memberikan tanggapan bahwa tidak tahu sama sekali mengenai apapun perubahan tarif tersebut baik tidak ada pada penyuluhan maupun iklan-iklan yang ada.

\subsection{Pembahasan}

Pelaksanaan Self Assessment System di Kota Tomohon. Menurut para informan wajib pajak UMKM, ada beberapa faktor yang menjadi alasan tidak maksimalnya sistem ini diberlakukan, yaitu sistem perpajakan yang rumit dan sulit untuk dimengerti masyarakat serta tidak ditunjang dengan penyuluhan yang merata, tingkat kepatuhan rendah dan beban pajak yang tinggi. Wajib pajak UMKM mengungkapkan bahwa sistem perpajakan self assessment memberatkan mereka karena menguras waktu, sulit untuk dimengerti serta tidak ditunjang dengan penyuluhan mulai dari tata cara menghitung, membayar dan melapor hingga perubahan-perubahan peraturan dan tarif yang tidak menyentuh seluruh golongan masyarakat. Terdapat dua informan yang menggunakan jasa ahli perpajakan atau konsultan pajak karena dianggap membantu dan dapat menjelaskan keseluruhan pajak lebih mendalam. Hal ini merupakan bukti nyata bahwa with-holding system lebih baik dimata masyarakat. Dari penelitian ini dapat dilihat bahwa faktor pengetahuan pajak adalah kunci tercapainya pelaksanaan self assessment system di kota Tomohon. Delapan dari sepuluh informan menjadi bukti bahwa pelaksanaan self assessment system belum tercapai dengan baik di Kota Tomohon. Jadi, pelaksanaan tersebut dapat tercapai apabila masyarakat wajib pajak memiliki setidaknya pengetahuan dasar dalam menghitung, membayar dan melapor pajak terutangnya.

Pemahaman Pajak pada Wajib Pajak UMKM Kota Tomohon. Melihat dari seluruh informan wajib pajak UMKM dapat memberikan penjelasan tentang pajak, maka tingkat pemahaman wajib pajak UMKM di kota Tomohon terbilang baik. Meski masih terdapat beberapa informan yang belum mengetahui pajak secara menyeluruh hal ini merupakan kemajuan dibidang perpajakan. Apabila masyarakat wajib pajak telah paham dan memiliki pengetahuan pajak yang menunjang, maka sistem self assessment bisa terlaksana dengan baik pada kota Tomohon, seperti sebagaimana pernyataan yang ditunjukan oleh Marziana, et al (2010) dalam Kuraesin (2013) yang mengungkapkan tentang adanya pemahaman dan pengetahuan wajib pajak akan memungkinkan wajib pajak untuk sadar dan patuh dalam hal ini dapat dalam mengimplementasikan sistem self assessment yang ada terdapat aspek untuk membayar pajak terutangnya, menghitung jumlah besaran pajaknya, pengembalian dalam jangka waktu yang ditetapkan, jujur dalam melaporkan dan akurat dalam menghitung.

Pelaksanaan Kewajiban Wajib Pajak UMKM Kota Tomohon. Dengan adanya tujuh responden hanya mampu menjalankan salah satu fungsi dan sisanya tidak menjalankan fungsi membayar dan melapor tepat waktu menjadi salah satu bukti dilapangan bahwa pada praktiknya sistem perpajakan ini justru memberatkan. Informan merespon bahwa kesulitan mereka terletak pada pengetahuan pajak yang tidak mendukung. Pengetahuan pajak yang kurang membuat informan kesulitan menjalankan kewajibannya sehingga informan-informan berdalih bahwa sosialisasi yang jarang ada membuat mereka buta pajak. Padahal jika ditinjau dari era modern saat ini bukan tidak mungkin mereka bisa mendapat sedikit pengetahuan perpajakan melalui smartphone atau sekedar website Dirjen pajak. Kemauan dan kesadaran 
yang kurang membuat masyarakat lebih cenderung selalu menyalahkan pemerintah. Fakta di lapangan membuktikan hanya ada tiga informan yang benar-benar menjalankan kewajiban perpajakannya dan dua diantaranya menggunakan jasa ahli perpajakan atau konsultan pajak. Informan bapak Tjung dan ibu Linda selaku sama-sama pemilik rumah makan menjelaskan bahwa dengan jasa ahli perpajakan mereka dapat menghemat waktu, menghindari kesalahan dalam perhitungan keuangan dan pemotongan pajak serta tidak khawatir pada pelaporan pajak. Tanpa sadar kedua informan ini mendukung with-holding system menjadi sistem yang lebih baik dan cocok digunakan. Padahal ada kerugian pada penggunaan jasa ahli tersebut, yaitu pembayaran atas jasa yang digunakan serta pengembangan kemampuan menghitung dan melaporkan pajak terutang sendiri. Kemampuan menghitung dan melaporkan pajak terutang sebenarnya dapat dikembangkan melalui pelatihan-pelatihan yang disosialisasikan oleh pemerintah (fiskus) untuk memberikan pengetahuan kepada masyarakat baik calon wajib pajak maupun wajib pajak agar menekan para pemilik NPWP fiktif yang hanya terdaftar tetapi tidak pernah menjalankan kewajibannya.

Kepekaan Wajib Pajak UMKM Kota Tomohon Terhadap Perubahan pada Perpajakan. Peneliti menemukan fakta bahwa tingkat kepekaan masyarakat wajib pajak UMKM di kota Tomohon tergolong rendah didukung dengan data yang menerangkan bahwa dari sepuluh responden hanya terdapat tiga responden yang mengetahui perubahan tarif tersebut. Tujuh informan lainnya memberikan penuturan bahwa tidak tahu akan perubahan tersebut dan tidak merasakan adanya dampak perubahan nyata pada usaha mereka. Berarti iklan, poster dan spanduk promosi penurunan tarif pajak final UMKM itu tidak berpengaruh pada tujuh responden wajib pajak UMKM tersebut. Ini bisa menjadi salah satu faktor mengapa tingkat kepedulian masyarakat wajib pajak kurang, yaitu kesadaran atau kepekaan mereka atas perubahan yang terjadi yang rendah. Jika ditinjau dari promosi besar-besaran yang dilakukan, kecil kemungkinan. Ada seorang informan mengungkap bahwa mereka di datangi oleh petugas pajak tetapi belum mengetahui tentang perubahan tarif pajak final UMKM $0,5 \%$. Jadi mereka tetap membayar pajak pada tarif normalnya dan tidak merasakan dampak apapun terhadap perubahan Hal ini cukup menarik karena mengingat promosi penurunan tarif pajak final UMK tersebut. Hal ini cukup menarik mengingat perubahan tarif pajak final UMKM ini adalah menjadi misi pemerintah saat ini juga bertujuan untuk dapat merangkul seluruh pelaku usaha UMKM tidak peduli dengan penghasilan berapapun agar membayar pajak sesuai dengan perubahan terbaru yang tertuang dalam Peraturan Pemerintah No. 23 Tahun 2018. Pada dasarnya masyarakat kurang peduli terhadap pajak karena dianggap memberatkan, ribet dan rumit hingga membuat masyarakat tidak peka akan perubahan yang terjadi meski didepan mata.

\section{KESIMPULAN DAN SARAN}

\subsection{Kesimpulan}

Menurut hasil dan pembahasan yang telah diuraikan sebelumnya, maka peneliti menarik kesimpulan dari penelitian ini adalah :

1. Pelaksanaan Self Assessment System di kota Tomohon belum berjalan dengan baik disebabkan oleh pengetahuan perpajakan yang kurang dan penyuluhan yang jarang diadakan oleh pemerintah (fiskus).

2. Tingkat pemahaman wajib pajak UMKM di kota Tomohon tergolong cukup baik mulai dari pengertian pajak hingga jenis-jenis pajak yang merupakan pengetahuan mendasar bagi masyarakat wajib pajak.

3. Pemenuhan kewajiban menghitung, membayar dan melaporkan wajib pajak UMKM di kota Tomohon masih rendah, berbanding terbalik dengan kemauan wajib pajak yang berkemauan untuk melaksanakannya namun terbentur dengan pengetahuan yang seadanya. 
4. Kepekaan dan kepedulian wajib pajak UMKM di kota Tomohon terhadap semua perubahan-perubahan yang dilakukan Dirjen pajak masih tergolong sangat rendah. Kepedulian masyarakat yang kurang padahal promosi yang dilakukan pemerintah (fiskus) sudah maksimal dengan baliho, spanduk, poster dan papan iklan.

\subsection{Saran}

Berdasarkan hasil penelitian yang telah dilakukan dan pembahasan yang telah dikemukakan, maka dapat disimpulkan bahwa:

1. Pendataan kembali pada wajib pajak UMKM di seluruh kota Tomohon mengingat perubahan PP No. 23 tahun 2018 tentang tidak ada pengecualian usaha dengan minimal pendapatan untuk membayar pajak.

2. Pemerintah khususnya Dirjen pajak terus melakukan sosialisasi dan penyuluhan mendalam pada semua pelaku usaha UMKM di kota Tomohon rutin minimal 1 bulan sekali khususnya pada kelurahan-kelurahan untuk meningkatkan pengetahuan perpajakan pada wajib pajak UMKM.

\section{DAFTAR PUSTAKA}

Agoes. 2013. Akuntansi Perpajakan. Salemba Empat. Jakarta.

Ajzen, I. 2005. Attitudes, Personality and behavior. Open University Press. New York.

Bitar. 2018. Pengertian Akuntansi Menurut Para Ahli \& (Fungsi, Jenis Dan Tujuan). Guru Pendidikan.com. Diakses pada tanggal 3 januari 2019.

Kuraesin, Mita. 2013. Pengaruh Pengetahuan Pajak dan Self Assessment System Terhadap Kepatuhan Pajak. Skripsi. Bandung

Kurnia, Siti Rahayu. 2018. Perpajakan Indonesia : Konsep dan Aspek Formal. Graha Ilmu. Yogyakarta.

Mardiasmo. 2016. Perpajakan Edisi Terbaru. CV Andi Offset. Yogyakarta.

Republik Indonesia. 2008. Undang-Undang No. 20 Tahun 2008 tentang Usaha Mikro Kecil dan Menengah. Lembaran Negara RI Tahun 2008, No. 93. Sekretariat Negara. Jakarta.

Waluyo. 2013. Perpajakan Indonesia. Salemba Empat. Jakarta.

Zain, Mohammad. 2008. Manajemen Perpajakan. Salemba Empat. Bandung. 